\title{
About the new Editor
}

IBAM welcomes Dr. David D. Van Fleet (Arizona State University at the West campus) as the new Editor of JBAM. Throughout his career David has integrated his writing, teaching, and professional service activity to achieve multiple goals. As of the end of 2005, David had over 230 publications and presentations as well as extensive teaching and professional service experience. He has over 40 years of full-time teaching experience that includes 55 different courses with more than 10,000 students. He is a Fellow of both the Academy of Management and the Southern Management Association; has been on the governing boards of the Academy of Management, SWFAD, and SMA; and has been President of SMA, ASBA, and the SW Academy, and Chair of the Management History Division of the Academy. He is listed in Who's Who in America $\left(57^{\text {th }}\right.$ edition, 2003) and Who's Who Among America's Teachers ( $7^{\text {th }}$ edition, 2002). His previous editorial experience includes serving as Editor of the Journal of Management, the Academy of Management's Newsletter, and the newsletter of the Management History Division.

\section{From the Editor}

Last Fall when I agreed to accept the Editorship of the Journal of Behavioral and Applied Management, I anticipated needing help from the members of the Institute of Behavioral and Applied Management. I did indeed need help and I have received it. You have been wonderful and I thank all of you for it. Maybe I can personally thank you at our October meeting in Memphis. IBAM's leadership has been great and its members very supportive.

The previous Editors-Dan Rowley, Herb Sherman, and John Humphreys-have all eased my transition into the Editor's role. Len White, as Associate Editor and IBAM Webmaster, has also been superb. I wanted to make JBAM completely an online journal-a vision that Len shared. The move has not been without glitches, but thanks to Len, we are probably over $90 \%$ there.

Fred Luthans has been a consulting editor for JBAM almost since its beginning, and I am pleased that he continues in that role. In addition to Fred, I asked John Humphreys as immediate past editor to continue as a consulting editor, and he agreed. A former colleague and wonderful friend, Charlotte Sutton, also agreed to be a consulting editor. With these three highly qualified folks providing guidance, my mistakes hopefully will be few.

I also publicly thank my Editorial Review board and ad hoc reviewers. They have been hard at work reviewing material submitted to JBAM and are doing a terrific, professional job. They have been cooperative, a pleasure with whom to work, and, most of all, fast! I certainly could not have done my job without them. 
Some recent changes and happenings of importance to IBAM and JBAM include:

- JBAM is rapidly becoming a fully functioning, completely online journal.

- JBAM has a "masthead" to inform readers of IBAM's and JBAM's leadership.

- JBAM now has an ISSN designation-1930 0158.

- We are listed with the online Directory of Open Access Journals (DOAJ_http://www.doaj.org/).

- And we are now part of ProQuest's ABI Inform.

These changes should increase the visibility of JBAM and IBAM, thereby helping to increase the quality and quantity of material appearing in JBAM.

\section{Some Guidelines on Writing and Publishing}

Recently I was asked to share my "secrets" of publishing. While I don't have any "secrets" for publishing journal articles, I do have some thoughts on how to approach the process. Sharing those "guidelines" with you may help and encourage you in some small way.

Note that these guidelines are not intended to be complete or definitive; they are just guidelines. They pertain to journal publishing and perhaps presentations and monographs, not textbook writing. And they pertain primarily to college and university faculty although practitioners wishing to publish may glean some ideas from them.

As indicated in the "About the new Editor" information above, I have not spent all of my time writing. I have tried to integrate my writing, teaching, and service activity to achieve multiple goals from the same activities. That's Guideline \#1.

\section{\#1 - Try to Integrate Your Teaching, Research and Service}

- Use students to help build databases

- Use students to critique ideas

- Consider having student co-authors-take the best term paper (graduate or undergraduate) and convert it into a possible article with the student as a co-author

- Serve on boards or committees related to your research or where you will interact with editors or others interested in your topics

- Volunteer to serve as an ad hoc reviewer or editorial board member for several journals as well as for regional and national meetings in your field 


\title{
\#2 - Have Something to Say
}

- Important to you

- Important to the field

- Important to practitioners

- Includes an UMPH or a WOW factor-a hook to get readers/editors interested

\author{
When I Was One-and-Twenty \\ (with apologies to A.E. Housman) \\ When I was one-and-twenty \\ I heard a wise man say, \\ "Publish meaningless empiricism and trite thoughts \\ But give not your important, creative ideas away; \\ Publish articles and speeches \\ But keep your imagination free." \\ But I was one-and-twenty, \\ No use to talk to me. \\ When I was one-and-twenty \\ I heard him say again, \\ "The creativity out of the research \\ Was never given in vain; \\ 'Tis paid with sighs a plenty \\ And sold for endless rue." \\ And I am two-and-twenty (plus a lot more), \\ And oh, 'tis true, 'tis true.
}

Or in plain English, use your creativity to develop novel approaches, methods, applications, or the like

\section{\#3 - Develop a Thick Skin}

- Get your colleagues to review your work before submitting it, and try to get feedback from those who are most active in publishing

- Don't take criticisms personally

- Send a rejected manuscript to another outlet fast-maybe even without reworking it

- In responding to reviewers and/or editors, be diplomatic-even when they don't know what they are talking about. Remember that they, not you, make the final accept/reject decision.

- Tailor your article to a particular journal—don't send empirical work to a review journal and vice versa 


\section{\#4 - Use Spelling and Grammar Checks, but Most of All . . . . Proofread}

- A sloppily written paper suggests sloppy theory or research and provides an easy handle upon which a reviewer can hang a rejection

- Get someone else (or two or three others) to read your "final" draft before submission. Others can catch spelling/grammatical errors and methodological or reasoning shortcomings (Note that the same folks used in Guideline \#3 could be used here, or a different set could be used to put more "eyes" on the paper before it goes to a journal)

\section{\#5 - Work with Others}

- Co-author with colleagues (Guideline \#1 suggested that on occasion you might have a student co-author; Guidelines \#3 and \#4 suggest that you share your work with others to get feedback before submitting a paper to a journal)

- I know that I have been far more productive working with others than I have been working alone

- A well-known researcher in management, however, used to tell his doctoral students that 1 out of every 7 papers should be sole authored to establish your identity and leadership in some area

\section{\#6 - Perform Writing-Related Activity Every Day}

- Try to do something in terms of your scholarship every day-takes notes on an article relevant to your work; gather some data; analyze some data; write a page; send a draft to colleagues for comments-just do something to keep yourself active and your work "moving along."

Well, that's it! I hope that you find these few guidelines useful.

\section{An Introduction to this Issue}

This issue of JBAM continues our tradition of offering a wide range of interesting papers and cases. Isaiah Ugboro addresses an important current issue in the first article, "Organizational Commitment, Job Redesign, Employee Empowerment and Intent to Quit among Survivors of Restructuring and Downsizing." He seeks to determine the relationship between job redesign, employee empowerment and intent to quit measured by affective organizational commitment among survivors of organizational restructuring and downsizing.

The second article, "Organizational Goals Versus the Dominant Coalition: A Critical View of the Value of Organizational Citizenship Behavior," by Wm. 
Matthew Bowler, presents a critical view of organizational citizenship behavior by examining the influence of informal power sources, such as the dominant coalition, on citizenship behavior.

Next, Anne Fiedler and Ivan Blanco present "The Challenge of Varying Perceptions of Sexual Harassment: An International Study." Using data based on legal and cultural differences in three countries as well as differing perceptions based on gender, they found significant differences in perceptions of sexual harassment according to country of residence, types of harassment, and gender scripts.

Then Sara Kimmel and Mary Nell McNeese address "Barriers to Business Education: Motivating Adult Learners." In their study involving nontraditional degree programs offered in faith-based colleges and one public institution in the U.S. and Canada, they found significant differences in motivations and barriers to enroll by gender and ethnicity.

The final article, "A Fresh Look at Followership: A Model for Matching Followership and Leadership Styles," by Kent Bjugstad, Elizabeth Thach, Karen Thompson, and Alan Morris, addresses the understudied and underappreciated topic of followership. The authors provide a fresh look at followership and a new model for matching followership styles to leadership styles.

Finally, we offer one teaching case in this issue. "The Reluctant Manager," by Herbert Sherman and Daniel James Rowley is a field-based disguised case that describes how a small family business deals with small business management, leadership, and subcontractor supervision. The case centers on a foreman's inability to manage the work of subcontractors. Following the lead of other organizations that publish cases, the teaching notes are included with the material read by our reviewers, but we do not publish those notes (they are available from the authors). This assures users of the case that students/clients are not able to "get the answers" from JBAM ahead of time.

\section{In Closing}

Finally, if you missed the Scottsdale Conference, we missed you and you missed a tremendous conference. Please plan to join us October 5-7 in Memphis, TN for IBAM 14. Memphis is a great city for a conference-good food, wonderful music, Beale Street, the Orpheum theatre, Mud Island, the Pyramid, the National Civil Rights Museum, and, of course, IBAM - the friendliest group of people you will ever meet! The deadline for submitting papers has passed, but you can still come and join in the collegial information exchange. I look forward to seeing you there.

David D. Van Fleet, Editor 